\title{
PENGARUH PRODUKTIVITAS KERJA DAN GAJI YANG DITERIMA TERHADAP KEPUASAN KERJA AUDITOR PADA KANTOR AKUNTAN PUBLIK DI DENPASAR
}

\author{
Ni Made Mira Yuni \\ Program Studi Pendidikan Ekonomi \\ Universitas Pendidikan Ganesha \\ Singaraja, Indonesia \\ e-mail : mirayuni706@gmail.com
}

\begin{abstract}
ABSTRAK
Penelitian ini bertujuan untuk mengetahui pengaruh produktivitas kerja dan gaji yang diterima terhadap kepuasan kerja baik secara parsial maupun simultan pada kantor akuntan publik di Denpasar. Penelitian ini termasuk dalam jenis penelitian kausal. Subjek dalam penelitian ini adalah auditor akuntan publik di Denpasar yang berjumlah 45 auditor. Data dikumpulkan dengan menggunakan kuesioner dan dianalisis menggunakan analisis regresi linier berganda dengan bantuan program statistical package for social sciences (SPSS) for windows versi 16. Hasil penelitian menunjukkan bahwa produktivitas kerja berpengaruh signifikan terhadap kepuasan kerja ditunjukkan dari nilai thitung $>$ tabel $(4.140>1.68)$, gaji yang diterima berpengaruh signifikan terhadap kepuasan kerja ditunjukkan dari nilai thitung > ttabel $(4.117>1.68)$, dan produktivitas kerja dan gaji yang diterima berpengaruh terhadap kepuasan kerja ditunjukkan dari nilai Fhitung $>F_{\text {tabel }}(47.416>3.22)$.
\end{abstract}

Kata kunci : Produktivitas Kerja, Gaji yang diterima, Kepuasan Kerja

\begin{abstract}
This study aimed to determine the effect of work productivity and salary received on job satisfaction either partially and simultaneously at public accounting firm in Denpasar. This research was included in this type of causal research. subject in this research was auditor of public accountant in Denpasar which amount to 45 auditor. Data were collected by using questionnaires and analyzed using multiple linear regression analysis with the help of statistical package for social sciences (SPSS) program for windows version 16. The results show that work productivity has a significant effect on job satisfaction shown from tcount> ttable (4.140> 1.68), the salary received significant effect on job satisfaction is shown from the value of tcount $>$ ttable $(4.117>1.68)$, and work productivity and salary received affect on job satisfaction is shown from the value Fcount $>$ Ftable $(47.416>3.22)$.
\end{abstract}

Keywords: Work Productivity, Salary received, Job Satisfaction

\section{PENDAHULUAN}

kerja yang baik sangat dipengaruhi
oleh perlakuan perusahaan terhadap
keberadaan karyawan yang dipengaruhi
oleh integritas dan sikap kerja mereka

dalam perusahaan. Kantor Akuntan Publik (KAP) merupakan perusahaan yang bergerak di bidang jasa keuangan yang dituntut untuk memiliki keunggulan kompetitif (competitif advantage) dan memberikan perhatian yang besar untuk 
p-ISSN : 2599-1418

e-ISSN : 2599-1426
Jurnal Pendidikan Ekonomi Undiksha

Volume 10 No. 1 Tahun 2018 meningkatkan kemampuan sumber daya manusia agar dapat memenangkan persaingan.

Menurut Arens dan Loebbecke (2003), auditor adalah seorang independen yang bertugas mengaudit atas laporan keuangan suatu perusahaan sesuai dengan prosedur audit yang berlaku dan benar. tujuan auditor adalah, untuk menentukan laporan keuangan tersebut wajar dalam material, posisi keuangan (gambaran suatu keadaan keuangan perusahaan yang ditunjukkan oleh nilai kekayaan dan utang perusahaan yang tercermin dari neraca perusahaan tersebut) dan hasil usaha perusahaan atau organisasi tersebut. Seorang auditor dituntut mampu bekerja secara maksimal dan profesional. Auditor yang professional dapat dilihat dari kerjanya saat menjalankan tugas sebagai seorang auditor. Menurut Guy (2002), jika dilihat dari pihak yang melakukan pemeriksaan maka terdapat dua kelompok auditor yaitu auditor internal dan auditor eksternal. Kedudukan dan tanggung jawab di antara kedua kelompok auditor tersebut sangat berbeda satu sama lain. Seorang auditor internal bekerja pada perusahaan, lembaga pemerintahan atau perusahaan nirlaba, sedangkan auditor eksternal bekerja pada suatu Kantor Akuntan Publik (KAP). Kepuasan kerja dari seorang auditor perlu dijamin oleh Kantor Akuntan Publik. Gautama dan Muhamad (2010) menyatakan bahwa, seorang auditor yang mempunyai tingkat kepuasan kerja tinggi menunjukkan kinerjanya dengan baik.

Menurut Stephen (1996) pengertian kepuasan kerja menurut Stephen $P$. Robbins adalah suatu sikap umum terhadap pekerjaan seseorang, selisih antara banyaknya ganjaran yang diterima seorang pegawai dan banyaknya yang mereka yakini apa yang seharusnya mereka terima. Menurut Hasibuan (2001) pengertian kepuasan kerja menurut Hasibuan adalah sikap emosional yang menyenangkan dan mencintai pekerjaannya. Sikap ini dicerminkan oleh moral kerja, kedisiplinan dan prestasi kerja. Kepuasan kerja dinikmati dalam pekerjaan, luar pekerjaan, dan kombinasi dalam dan luar pekerjaan. Menurut Luthans (2006) pengertian kepuasan kerja menurut Luthans adalah hasil dari persepsi karyawan mengenai seberapa baik pekerjaan mereka memberikan hal yang dinilai penting. Menurut Robins (2003), kepuasan kerja adalah suatu hal yang bersifat individual. Setiap individu mempunyai tingkat kepuasan yang berbeda. Menurut Marihot (2009), kepuasan kerja adalah merupakan salah satu elemen yang cukup penting dalam organisasi. Hal ini disebabkan kepuasan kerja dapat mempengaruhi perilaku kerja seperti malas, rajin, produktif, atau mempunyai hubungan beberapa jenis perilaku yang sangat penting dalam organisasi.

Menurut Handoko (2007), kepuasan kerja adalah keadaan emosional yang menyenangkan atau tidak menyenangkan dimana para karyawan memanadang pekerjaan mereka. Menurut Veitzal (2003) kepuasan kerja (job satisfaction) adalah keadaan emosional yang menyenangkan atau tidak menyenangkan di mana para karyawan memandang pekerjaanya. Kepuasan kerja mencerminkan perasaan seseorang terhadap pekerjaanya. Hal ini tampak pada sikap positif karyawan terhadap pekerjaan dan segala sesuatu yang dihadapi di lingkungan kerjanya. Departemen sumber daya manusia atau manajemen harus selalu memonitor kepuasan kerja karena hal ini memengaruhi sikap absensi, perputaran tenaga kerja, kepuasan kerja dan masalahmasalah penting lainya.

Menurut Veitzal (2000) secara teoritis, faktor-faktor yang mempengaruhi kepuasan kerja sangat banyak jumlahnya, seperti gaya kepemimpinan, produktivitas kerja, perilaku, locus of control, gaji yang sesuai, dan efektivitas kerja. menurut Woekirno produktivitas adalah kesadaran untuk menghasilkan sesuatu yang lebih banyak daripada yang telah atau sedang berada dalam usahanya. Produktivitas kerja merupakan perbandingan terbaik antara 
hasil yang diperoleh dengan jumlah kerja yang dikeluarkan. Produktivitas kerja dikatakan tinggi jika hasil yang diperoleh lebih besar dari pada sumber tenaga kerja yang dipergunakan dan sebaliknya, Produktivitas yang diukur dari daya guna (efisiensi penggunaan personal sebagai tenaga kerja). Menurut Sinungan (2003), pengukuran produktivitas kerja pada dasarnya digunakan untuk mengetahui sejauh mana tingkat efektivitas dan efisiensi kerja karyawan dalam menghasilkan suatu hasil. Dalam usaha untuk dapat mengukur tingkat kemampuan karyawan dalam mencapai sesuatu hasil yang lebih baik dan ketentuan yang berlaku. Menurut J. Ravianto (2000), pengukuran produktivitas ini mempunyai peranan yang sangat penting untuk mengetahui produktivitas kerja sesuai dengan yang diharapkan perusahaan.

Dalam penelitian ini yang menjadi pengukuran produktivitas kerja yaitu penggunaan waktu dan hasil kerja atau output.Produktivitas ini digambarkan dari ketepatan penggunaan metode atau cara kerja dan alat yang tersedia, sehingga volume dan beban kerja dapat diselesaikan sesuai dengan waktu yang tersedia. Hasil yang diperoleh bersifat non material yang tidak dapat dinilai dengan uang, sehingga produktivitas hanya digambarkan melalui efisiensi personal dalam pelaksanaan tugastugas pokoknya.

Peningkatan produktivitas merupakan dambaan setiap perusahaan, produktivitas mengandung pengertian berkenaan dengan konsep ekonomis, filosofis, produktivitas berkenaan dengan usaha atau kegiatan manusia untuk menghasilkan barang atau jasa yang berguna untuk pemenuhan kebutuhan hidup manusia dan masyarakat pada umumnya. Sebagai konsep filosofis, produktivitas mengandung pandangan hidup dan sikap mental yang selalu berusaha untuk meningkatkan mutu kehidupan dimana keadaan hari ini harus lebih baik dari hari kemarin, dan mutu kehidupan hari esok harus lebih baik dari hari ini. Hal ini yang memberi dorongan untuk berusaha dan mengembangkan diri. Sedangkan konsep sistem, memberikan pedoman pemikiran bahwa pencapaian suatu tujuan harus ada kerja sama atau keterpaduan dari unsurunsur yang relevan sebagai sistem.

Produktivitas pada dasarnya mencakup sikap mental yang selalu mempunyai pandangan bahwa kehidupan hari kemarin harus lebih baik dari hari ini. Cara kerja hari ini harus lebih baik dari hari kemarin dan hasil kerja yang dicapai esok hari harus lebih baik dari yang diperoleh hari ini. Menurut Payman (2000:34-35), "pengertian tersebut menjelaskan bahwa di dalam meningkatkan produktivitas kerja memerlukan sikap mental yang baik dari pegawai, disamping itu peningkatan produktivitas kerja dapat dilihat melalui cara kerja yang digunakan dalam melaksanakan kegiatan dan hasil kerja yang diperoleh. Sehingga dari pengertian tersebut dapat disimpulkan bahwa di dalam produktivitas kerja terdapat unsur pokok yang merupakan kriteria untuk menilainya.

Menurut Komarudin (2008:121), "produktivitas pada hakekatnya meliputi sikap yang senantiasa mempunyai pandangan bahwa metode kerja hari ini harus lebih baik dari metode kerja kemarin dan hasil yang dapat diraih esok harus lebih banyak atau lebih bermutu daripada hasil yang diraih hari ini.Menurut Sedarmayanti (1999) produktivitas adalah "keinginan dan upaya manusia untuk selalu meningkatkan kualitas kehidupan dan penghidupan di segala bidang". Menurut Riyanto (1986) Pengertian "produktivitas secara tidak langsung menyatakan kemajuan dari proses transformasi sumber daya menjadi barang atau jas, peningkatan berarti perbandingan yang naik antara sumber daya yang dipakai (input) dengan jumlah barang yang dihasilkan (output)".Menurut Amillin (2008), kepuasan kerja seseorang juga dipengaruhi dari dalam maupun dari luar.Untuk sisi internal kepuasan kerja seseorang dipengaruhi produktivitas kerja dan gaji, sedangkan dari sisi eksternal kepuasan kerja seseorang dipengaruhi oleh presepsi individu. Menurut Wibowo (2012), salah satu 
p-ISSN : 2599-1418

e-ISSN : 2599-1426

faktor yang mempengaruhi kepuasan kerja adalah kebijakan dalam pemberian kompensasi (gaji) oleh perusahaan kepada karyawannya. Secara normatif, kepuasan kerja auditor ditunjukkan oleh rasa puasnya pegawai terhadap imbalan yang didapatkanya dari pekerjaannya. Menurut Hariandja (2002) gaji merupakan salah satu unsur yang penting yang dapat mempengaruhi kinerja karyawan, sebab gaji adalah alat untuk memenuhi berbagai kebutuhan pegawai, sehingga dengan gaji yang diberikan pegawai akan termotivasi untuk bekerja lebih giat. Sastro (2006), gaji dapat berperan dalam meningkatkan motivasi karyawan untuk bekerja lebih efektif, meningkatkan kinerja, meningkatkan produktivitas dalam perusahaan, serta mengimbangi kekurangan dan keterlibatan komitmen yang menjadi ciri angkatan kerja masa kini. Perusahaan yang tergolong modern, saat ini banyak mengaitkan gaji dengan kinerja. Menurut Mathis dan Lackson (2002), gaji adalah suatu bentuk kompensasi yang dikaitkan dengan kinerja individu, kelompok ataupun kinerja organisasi.

Berdasarkan uraian tersebut di atas, maka dapat disimpulkan bahwa Gaji adalah balas jasa atau penghargaan atas prestasi kerja, yang harus dapat memenuhi kebutuhan hidup bersama keluarganya secara layak, sehingga ia dapat memusatkan perhatiannya dan kegiatannya untuk melaksanakan tugas yang dipercayakan kepadanya. Menurut Siagian (2008), sistem imbalan atau gaji yang baik adalah sistem yang mampu menjamin kepuasan kerja para anggota organisasi sehingga organisasi tersebut memeroleh, memelihara dan mempekerjakan sejumlah anggota yang memiliki sikap perilaku produktif bagi kepentingan organisasi. Sebaliknya, apabila gaji yang diterima para anggota organisasi tidak sesuai maka terjadi ketidakpuasan kerja yang dampaknya bagi organisasi bersifat negatif. Menurut Martoyo (2000), selain faktor gaji, faktor lain yang dapat mempengaruhi kepuasan kerja auditor yaitu produktivitas kerja.
Jurnal Pendidikan Ekonomi Undiksha Volume 10 No. 1 Tahun 2018

Produktivitas kerja merupakan sikap yang senantiasa mempunyai pandangan bahwa hasil yang dapat diraih esok harus lebih banyak atau lebih bermutu daripada hasil yang diraih hari ini. Produktivitas kerja mempunyai kaitan yang erat dengan keinginan atau kemauan seseorang untuk mencapai sesuatu yang lebih baik. Menurut Siagian (2003), produktivitas adalah kemampuan memeroleh manfaat sebesarbesarnya dari sarana dan prasarana yang tersedia dengan menghasilkan keluaran (output) yang optimal bahkan kemungkinan yang maksimal. Produktivitas kerja merupakan suatu masalah yang harus mendapat perhatian serius dari pihak perusahaan, karena peningkatan produktivitas kerja karyawan tidak terjadi dengan sendirinya, tetapi harus ada usaha dan peran, baik dari pihak perusahaan maupun dari pihak karyawan itu sendiri.

Kepuasan kerja karyawan yang tinggi cenderung meningkatkan produktivitas kerja karyawan yang juga berdampak positif pada pencapaian tujuan perusahaan. Aspek pemberi gaji, Gaji merupakan unsur pokok dalam menghitung biaya produksi dan komponen dalam menentukan harga pokok yang dapat menentukan kelangsungan hidup perusahaan. Apabila suatu perusahaan memberikan gaji terlalu tinggi maka, akan mengakibatkan harga pokok tinggi pula dan bila gaji yang diberikan terlalu rendah akan mengakibatkan perusahaan kesulitan mencari tenaga kerja.

Aspek penerimaan gaji, gaji merupakan penghasilan yang diterima oleh seseorang dan digunakan untuk memenuhi kebutuhanannya. Gaji bukanlah merupakan satu-satunya motivasi karyawan dalam berprestasi, tetapi gaji merupakan salah satu motivasi penting yang ikut mendorong karyawan untuk berprestasi, sehingga tinggi rendahnya gaji yang diberikan akan mempengaruhi kinMenurut Komaruddin (2002) fungsi gaji bukan hanya membantu manajer personalia dalam menentukan gaji yang adil dan layak saja, tetapi masih ada fungsi-fungsi yaitu, pertama, untuk 
p-ISSN : 2599-1418

e-ISSN : 2599-1426
Jurnal Pendidikan Ekonomi Undiksha Volume 10 No. 1 Tahun 2018 mendorong pekerja agar menunjukkan prestasi yang tinggi. Dan kedua, untuk memelihara prestasi pekerja selama periode yang panjangerja dan kesetiaan karyawan.

Berdasarkan hasil observasi awal yang peneliti lakukan di Kantor Akuntan Publik (KAP) di Denpasar, gaji akuntan per bulan menurut tingkat pengalaman kerja adalah (a) tidak ada pengalaman gajinya Rp. 1.530.953; (b) kurang dari 5 tahun pengalaman gajinya Rp. 2.021.4943.195 .797 ; (c) 5-10 tahun pengalaman gajinya Rp. 3.452.976- 4.689.080 dan (d) lebih dari 10 tahun pengalaman gajinya $R p$. $>5.104 .908$.

Penulis ingin meneliti mengenai pengaruh antara produktivitas kerja dan gaji yang diterima terhadap kepuasan kerja auditor. Hal tersebut dikarenakan peneliti melihat ketidak seimbangan antara gaji yang diterima auditor dengan beban kerja sehingga berdampak pada tingkat kepuasan kerja auditor, jika produktivitas kerja auditor rendah maka gaji yang diterima juga rendah sehingga dapat mempengaruhi kepuasan kerja auditor, namun jika produktivitas kerja auditor tinggi maka gaji yang diterima juga tinggi dan akan berpengaruh terhadap kepuasan kerja auditor.

Menurut Ati Cahayani (2005), sumber daya manusia merasa dihargai jika gaji pegawai disesuaikan dengan beban pekerjaan, namun kenyataan yang ada di lapangan keadaanya berbanding terbalik dengan teori, sehingga diperlukan penelitian lebih lanjut tentang "Pengaruh Produktivitas Kerja dan Gaji yang Diterima Terhadap Kepuasan Kerja Auditor Pada Kantor Ankutan Publik di Denpasar.

\section{METODE}

Penelitian ini merupakan jenis penelitian kausalitas. Penelitian ini bertujuan untuk mengetahui pengaruh dari variabel bebas terhadap variabel terikat. Adapun yang menjadi variabel bebas dalam penelitian ini adalah produktivitas kerja dan gaji yang diterima sedangkan variabel terikatnya adalah kepuasan kerja. Hasil yang diharapkan dalam penelitian ini yaitu dapat mengetahui seberapa besar produktivitas kerja dan gaji yang diterima berpengaruh terhadap kepuasan kerja auditor pada kantor akuntan publik di Denpasar.

Dalam Penelitian ini yang menjadi subjek dalam penelitian adalah auditor akuntan publik di Denpasar,dan Objek penelitian adalah produktivitas kerja, gaji yang diterima dan kepuasan kerja auditor akuntan publik di denpasar. Jenis data yang digunakan dalam penelitian ini adalah data kuantitatif dan sumber data yang digunakan yaitu data primer dan sekunder. Metode pengumpulan data dalam penelitian ini adalah menggunakan angket atau kuesioner. Penyebaran kuesioner ini dilakukan secara langsung dengan memberikan kuesioner yang berisi daftar pertanyaan yang telah disusun kepada responden yaitu auditor kantor akuntan publik di Denpasar. Penelitian ini menggunakan intrumen berupa kuesioner. Skala yang digunakan dalam penyusunan kuesioner adalah Skala Likert dengan satuan ukur ordinal. Penelitian ini menggunakan teknik analisis data yaitu regresi linier berganda untuk mengetahui pengaruh variabel bebas $(X)$ terhadap variabel terikat (Y) melalui program komputer SPSS 16 dan melakukan uji asumsi klasik.

\section{HASIL DAN PEMBAHASAN Hasil}

Berdasarkan perhitungan analisis data, pengaruh produktivitas Kerja terhadap kepuasan kerja auditor pada kantor akuntan publik di Denpasar dapat dilihat pada tabel 1. 
Tabel 1. Hasil Uji T Untuk Variabel Produktivitas Kerja

\begin{tabular}{|c|c|c|c|c|c|c|}
\hline \multirow[b]{2}{*}{ Model } & & \multicolumn{2}{|c|}{$\begin{array}{l}\text { Unstandardized } \\
\text { Coefficients }\end{array}$} & \multirow{2}{*}{$\begin{array}{l}\text { Standardized } \\
\text { Coefficients } \\
\text { Beta }\end{array}$} & \multirow[b]{2}{*}{$t$} & \multirow[b]{2}{*}{ Sig. } \\
\hline & & B & Std. Error & & & \\
\hline \multirow[t]{2}{*}{1} & (Constant) & -5.265 & 3.974 & & -1.325 & .192 \\
\hline & $\begin{array}{l}\text { Produktivitas } \\
\text { Kerja }\end{array}$ & .605 & .146 & .461 & 4.140 & .000 \\
\hline
\end{tabular}

Berdasarkan tabel 1 menunjukkan produktivitas kerja memiliki pengaruh yang bahwa variabel produktivitas kerja signifikan terhadap kepuasan kerja auditor berpengaruh signifikan terhadap kepuasan pada kantor akuntan publik di Denpasar. kerja, karena nilai thitung $=4.140>$ ttabel Pengaruh gaji yang diterima terhadap $=1.68$ atau $p$-value $=0.000<\alpha=0.05 \quad$ kepuasan kerja auditor pada kantor maka HO ditolak. Oleh karena itu, maka akuntan publik di Denpasar dapat dilihat dapat disimpulkan bahwa variabel pada tabel 2

Tabel 2. Hasil Uji t untuk Variabel Gaji yang diterima

\begin{tabular}{|c|c|c|c|c|c|c|}
\hline \multirow[b]{3}{*}{ Model } & & \multicolumn{2}{|c|}{ Unstandardized } & Standardized & \multirow[b]{3}{*}{$t$} & \multirow[b]{3}{*}{ Sig. } \\
\hline & & Coeffic & ients & Coefficients & & \\
\hline & & B & Std. Error & Beta & & \\
\hline \multirow[t]{2}{*}{1} & (Constant) & -5.265 & 3.974 & & -1.325 & .192 \\
\hline & $\begin{array}{l}\text { Gaji yang } \\
\text { diterima }\end{array}$ & .510 & .124 & .458 & 4.117 & .000 \\
\hline
\end{tabular}

Berdasarkan tabel 2 menunjukkan bahwa variabel gaji yang diterima berpengaruh signifikan terhadap kepuasan kerja, karena nilai thitung $=4.117>$ tabel $=1.68$ atau p-value $=0.000<\alpha=0.05$ maka $\mathrm{HO}$ ditolak. Oleh karena itu, maka dapat disimpulkan bahwa variabel gaji yang diterima berpengaruh secara signifikan terhadap kepuasan kerja auditor pada kantor akuntan publik di Denpasar.

Pengaruh produktivitas kerja Dan gaji yang diterima terhadap kepuasan kerja auditor pada kantor akuntan publik di Denpasar dapat dilihat pada tabel 3 .

Tabel 4.3 Hasil Perhitungan Uji F

\begin{tabular}{|c|c|c|c|c|c|c|}
\hline \multicolumn{7}{|c|}{ ANOVA $^{b}$} \\
\hline & Model & Sum of Squares & Df & Mean Square & $\mathrm{F}$ & Sig. \\
\hline \multirow[t]{3}{*}{1} & Regression & 926.478 & 2 & 463.239 & 47.416 & $.000^{\mathrm{a}}$ \\
\hline & Residual & 410.322 & 42 & 9.770 & & \\
\hline & Total & 1336.800 & 44 & & & \\
\hline
\end{tabular}

Berdasarkan tabel 3 menunjukkan bahwa Fhitung $=47.416>F_{\text {tabel }}=3.22$ atau $p$-value $=0.000<\alpha=0,05$ hal ini berarti HO ditolak. Oleh karena itu, maka dapat disimpulkan bahwa variabel produktivitas kerja dan gaji yang diterima 
p-ISSN : 2599-1418

e-ISSN : 2599-1426
Jurnal Pendidikan Ekonomi Undiksha Volume 10 No. 1 Tahun 2018 memiliki pengaruh yang signifikan terhadap variabel kepuasan kerja auditor pada kantor akuntan publik di Denpasar.

Untuk mengetahui besarnya pengaruh produktivitas kerja dan gaji yang diterima terhadap kepuasan kerja, maka dapat digunakan analisis koefisien determinasi (Adjusted R) Square). Besarnya koefisien determinasi (Adjusted $R$ Square) dapat dilihat pada tabel 4.

Tabel 4. Hasil Perhitungan Koefisien Determinasi (Adjusted

\begin{tabular}{|c|c|c|c|c|}
\hline \multirow[b]{2}{*}{ Model } & \multicolumn{4}{|c|}{ Rsquare) } \\
\hline & $\mathrm{R}$ & R Square & $\begin{array}{l}\text { Adjusted R } \\
\text { Square }\end{array}$ & $\begin{array}{l}\text { Std. Error of } \\
\text { the Estimate }\end{array}$ \\
\hline 1 & $.833^{\mathrm{a}}$ & .693 & .678 & 3.12563 \\
\hline
\end{tabular}

Berdasarkan hasil analisis pada tabel 4 dengan menggunakan program SPSS 16.0 for windows menunjukkan bahwa besarnya pengaruh variabel produktivitas kerja dan gaji yang diterima terhadap variabel kepuasan kerja sebesar 0,678 sehingga sumbangan pengaruh untuk variabel produktivitas kerja (X1) dan gaji yang diterima (X2) terhadap kepuasan kerja (Y) adalah sebesar 67,8\%. Hal ini berarti kepuasan kerja auditor pada kantor akuntan publik di Denpasar sebesar $67,8 \%$ dipengaruhi oleh variabel produktivitas kerja dan gaji yang diterima, sedangkan sisanya sebesar 32,2 \% dipengaruhi oleh faktor lain yang tidak termasuk dalam penelitian ini.

Berdasarkan hasil analisis data, untuk mengetahui persamaan regresi pengaruh produktivitas kerja dan gaji yang diterima terhadap kepuasan kerja auditor pada kantor akuntan publik di Denpasar digunakan nilai. Unstandardized Coefficients Beta dapat dilihat pada tabel 5 .

Tabel 5. Hasil Uji t untuk Variabel Produktivitas kerja dan gaji yang diterima

\begin{tabular}{|c|c|c|c|c|c|c|}
\hline \multirow{3}{*}{\multicolumn{2}{|c|}{ Model }} & \multirow{2}{*}{\multicolumn{2}{|c|}{$\begin{array}{c}\text { Unstandardized } \\
\text { Coefficients }\end{array}$}} & \multirow{2}{*}{$\begin{array}{c}\text { Standardized } \\
\text { Coefficients }\end{array}$} & \multirow[b]{3}{*}{$\mathrm{t}$} & \multirow[b]{3}{*}{ Sig. } \\
\hline & & & & & & \\
\hline & & B & Std. Error & Beta & & \\
\hline \multirow[t]{3}{*}{1} & (Constant) & -5.265 & 3.974 & & -1.325 & .192 \\
\hline & $\begin{array}{l}\text { Produktivitas } \\
\text { kerja }\end{array}$ & .605 & .146 & .461 & 4.140 & .000 \\
\hline & $\begin{array}{l}\text { Gaji yang } \\
\text { diterima }\end{array}$ & .510 & .124 & 458 & 4.117 & .000 \\
\hline \multicolumn{4}{|c|}{$\begin{array}{l}\text { Berdasarkan hasil analisis pada } \\
5 \text { dengan mengunakan program }\end{array}$} & $\begin{array}{l}\mathrm{Y}=\text { kepuasan kerja } \\
\mathrm{X}_{1}=\text { produktivitas kerja }\end{array}$ & $\begin{array}{l}\text { erja } \\
\text { ima }\end{array}$ & \\
\hline
\end{tabular}

tabel 5 dengan mengunakan program SPSS 16.0 for windows dapat dibuat persamaan garis regresi. Persamaan garis regresi yang dapat dibuat untuk menggambarkan pengaruh Produktivitas kerja dan gaji yang diterima terhadap kepuasan kerja adalah sebagai berikut.

$\hat{Y}=-5.265+0.605 X_{1}+0.510 X_{2}$ Keterangan:
Interpretasi dari model regresi di atas adalah. Pertama, konstanta -5.265 menunjukkan bahwa jika variabel bebas produktivitas kerja (X1) dan gaji yang diterima (X2) sama dengan nol, maka kepuasan kerja (Y) akan mengalami kenaikan sebesar -5.265 satuan. Kedua, koefisien regresi 0.605 berarti jika variabel 
produktivitas kerja (X1) meningkat tiap satu satuan, maka kepuasan kerja (Y) akan mengalami peningkatan sebesar 0.605 dengan syarat variabel bebas lainnya tetap. dan ketiga, koefisien regresi 0.510 berarti jika variabel gaji yang diterima meningkat tiap satu satuan, maka kepuasan kerja (Y) akan mengalami peningkatan sebesar 0.510 dengan syarat variabel bebas lainnya tetap.

Berdasarkan persamaan regresi linier berganda yang dihasilkan, dapat ditunjukkan bahwa produktivitas kerja dan gaji yang diterima berpengaruh positif terhadap kepuasan kerja auditor pada kantor akuntan publik di Denpasar.

\section{PEMBAHASAN}

Berdasarkan hasil penelitian yang dilakukan mengenai pengaruh produktivitas kerja dan gaji yang diterima terhadap kepuasan kerja auditor pada kantor akuntan publik di Denpasar. Temuan ini mendukung teori yang dikemukakan oleh Amillin (2008), kepuasan kerja seseorang juga dipengaruhi dari dalam maupun dari luar. Untuk sisi internal kepuasan kerja seseorang dipengaruhi produktivitas kerja dan gaji, sedangkan dari sisi eksternal kepuasan kerja seseorang dipengaruhi oleh presepsi individu.

Hasil temuan ini menunjukkan bahwa variabel produktivitas kerja memiliki pengaruh yang signifikan terhadap kepuasan kerja auditor pada kantor akuntan publik di Denpasar. Produktivitas kerja merupakan sikap yang senantiasa mempunyai pandangan bahwa hasil yang dapat diraih esok harus lebih banyak atau lebih bermutu daripada hasil yang diraih hari ini. Produktivitas kerja mempunyai kaitan yang erat dengan keinginan atau kemauan seseorang untuk mencapai sesuatu yang lebih baik. Hasil penelitian ini sejalan dengan teorinya Rusli Syarif (2002) yang mengungkapkan bahwa ada pengaruh dari produktivitas kerja dan kualitas yang dihasilkan dengan jumlah kerja yang dilakukan. Sedangkan secara umum bahwa produktivitas merupakan ratio antara kepuasan atas kebutuhan dan pengorbanan yang dilakukan. Hasil penelitian ini juga mendukung teorinya Basu Swastha dan Ibnu Sukotjo (2005) yang menyatakan bahwa produktivitas merupakan sebuah konsep yang menggambarkan hubungan antara hasil (jumlah barang dan jasa) dengan sumber (jumlah tenaga kerja, modal, tanah, energi, dan sebagainya) yang dipakai untuk menghasilkan hasil tersebut. Temuan ini juga sejalan dengan penelitian yang dilakukan oleh Hian Ayu Oceani Wibowo yang menyatakan bahwa produktivitas kerja dan komitmen berpengaruh positif terhadap kepuasan kerja di kantor akuntan publik.

Selain produktivitas kerja, gaji yang diterima juga memiliki pengaruh yang signifikan terhadap kepuasan kerja. Secara normatif, kepuasan kerja auditor ditunjukkan oleh rasa puasnya pegawai terhadap imbalan yang didapatkanya dari pekerjaannya. Sistem imbalan atau gaji yang baik adalah sistem yang mampu menjamin kepuasan kerja para anggota organisasi sehingga organisasi tersebut memeroleh, memelihara dan mempekerjakan sejumlah anggota yang memiliki sikap perilaku produktif bagi kepentingan organisasi. Sebaliknya, apabila gaji yang diterima para anggota organisasi tidak sesuai maka terjadi ketidakpuasan kerja yang dampaknya bagi organisasi bersifat negatif. Hasil penelitian ini mendukung teori dari Vahrizal Rifai (2000) yang menyatakan bahwa latar belakang timbulnya kepuasan kerja adalah gaya kepemimpinan, produktivitas kerja, perilaku, locus of control, gaji yang sesuai, dan efektivitas kerja. Temuan ini juga sejalan dengan penelitian yang dilakukan Hadiwiryo (2006), yang menyatakan gaji dapat berperan dalam meningkatkan motivasi karyawan untuk bekerja lebih efektif, meningkatkan kinerja, meningkatkan produktivitas dalam perusahaan, serta mengimbangi kekurangan dan keterlibatan komitmen yang menjadi ciri angkatan kerja masa kini. Perusahaan yang tergolong modern, saat ini banyak mengaitkan gaji 
p-ISSN : 2599-1418

e-ISSN : 2599-1426

dengan kinerja. gaji adalah suatu bentuk kompensasi yang dikaitkan dengan kinerja individu, kelompok ataupun kinerja organisasi.

\section{Simpulan dan Saran Simpulan}

Berdasarkan hasil penelitian dan pembahasan, maka dapat disimpulkan. Pertama, produktivitas kerja berpengaruh signifikan terhadap kepuasan kerja auditor pada kantor akuntan publik di Denpasar. Hal tersebut ditunjukkan dari hasil analisis ttes yang menunjukkan bahwa nilai thitung $=4.140>$ ttabel $=1.68$ atau $p$ value $=0.000<\alpha=0.05$. Kedua, gaji yang diterima berpengaruh signifikan terhadap kepuasan kerja auditor pada kantor akuntan publik di Denpasar. Hal tersebut ditunjukkan dari hasil analisis ttes yang menunjukkan bahwa nilai thitung $=$ $4.117>$ tabel $=1.68$ atau $p$-value $=$ $0.000<\alpha=0.05$. Ketiga, produktivitas kerja dan gaji yang diterima berpengaruh signifikan terhadap kepuasan kerja auditor pada kantor akuntan publik di Denpasar. Hal tersebut ditunjukkan dari hasil analisis Ftes yang menunjukkan bahwa nilai bahwa Fhitung $=47.416>$ Ftabel $=3.22$ atau $p$-value $=0.000<\alpha=0,05$. Besarnya pengaruh dari variabel produktivitas kerja dan gaji yang diterima terhadap kepuasan kerja adalah sebesar $67,8 \%$ sedangkan sisanya sebesar $32,2 \%$ dipengaruhi oleh faktor lain yang tidak termasuk dalam penelitian ini.

\section{Saran}

Berdasarkan simpulan di atas, maka dapat dikemukakan saran sebagai berikut. Pertama, untuk meningkatkan kepuasan kerja perlu adanya gaji yang sesuai. Salah satu cara yang dapat diterapkan agar pemberian gaji berdasarkan upah minimum (UMP) yang telah ditetapkan oleh pemerintah. Dan kedua, selain itu cara yang dapat diterapkan agar pemberian gaji menjadi
Jurnal Pendidikan Ekonomi Undiksha Volume 10 No. 1 Tahun 2018

efektif adalah dengan menggunakan penggajian berdasarkan sistem kontribusi karyawan. Kontribusi yang dimaksud disini bisa bervariasi, mulai dari absensi, kterlambatan, lama bekerja, atapun skor atau nilai berdasarkan job description para karyawan. Dengan begitu dapat dicapai sebuah tolok ukur bagi perusahaan untuk memberikan gaji kepada para karyawan yang tidak hanya sesuai dengan UMP, namun juga menjadi motivasi bagi para karyawan dalam kantor akuntan publik. Karena ketika auditor memiliki kepuasan kerja yang tinggi, produktivitas mereka pun meningkat di saat bekerja. Bagi peneliti lain yang bermaksud melakukan penelitian di bidang kepuasan kerja khususnya yang tertarik dan berminat untuk mendalami tentang produktivitas kerja dan gaji yang diterima, diharapkan untuk mengembangkan penelitian ini dengan menambah sampel atau populasi yang lebih luas agar dapat menguji variabel lain yang diduga kuat dapat mempengaruhi kepuasan kerja..

\section{DAFTAR PUSTAKA}

Arens \& loebbecke. 2003. Akuntansi Keprilakuan. Edisi 2: Jakarta, Penerbit Salemba Empat.

Amillin. 2008. Manajemen Motivasi. Jakarta: PT. Grasindo.

Ati, C, 2005. manajemen sumber daya manusia. Edisi 2, Yogyakarta: Penerbit BPFE.

Basu Swastha, Ibnu Sukotjo, 2005. Manajemen kinerja. Edisi 2, Yogyakarta: Penerbit BPFE.

Guy, Dan M. 2002. Manajemen dan Pengembangan Sumber Daya Manusia Yogyakarta , Penerbit CAPS.

Gautama, \& Muhamad. 2010 Sistem Manajemen Kinerja. Jakarta : PT Bumi

Aksara 
Handoko, T. Hani. 2007. Mengukur Kepuasan Kerja. Jakarta: Erlangga.

Hariandja, M. 2002. Manajemen Sumber Daya Manusia. Jakarta : grasindo.

Hasibuan, 2001. Manajemen Kinerja. Yogyakarta: BPEF.

Luthans, 2006. Manajemen Sumber Daya Manusia, Jakarta: Penerbit PT. Grasindo.

Marihot Tua Efendi. 2003. Manajemen Sumber Daya Manusia: Pengadaan, Pengembangan, Pengkompensasian, dan Peningkatan Produktivitas Pegawai. Jakarta: grasindo.

Martoyo. 2000. Pemahaman Praktis Manajemen Sumber Daya Manusia, Bandung: Mandar Maju.

Mathis, Robert L. 2002. Manajemen Sumber Daya Manusia. Jakarta: salemba 4.

Robbins. 2003. Sumber Daya Manusia, Edisi Pertama, Yogyakarta, BPFE

Riyanto. 1986. Manajemen Personalia dan Sumber Daya Manusia, Edisi kedua ,Yogyakarta, BPFE.

Sastrohadiwiryo, B. Siswanto. 2006. Manajemen Tenaga Kerja Indonesia. Bumi Aksara, Jakarta.

Sedarmayanti. 1999. Manajemen Sumber Daya Manusia, Jakarta: BPFE.

Simanjuntak, Payaman J. 2005. Manajemen dan Evaluasi Kinerja. Jakarta: FE UI.

Veitzal, Rivai. 2003, Manajemen Sumber Daya Manusia untuk Perusahaan: Dari. Teori ke Praktik. Jakarta: PT.Rajagrafindo Persada.

Wibowo. 2012. manajemen sumber daya manusia. Edisi 2, Yogyakarta: Penerbit BP.STIEYKPN. 